\title{
Perkembangan Pendidikan Islam di Indonesia dan Upaya Penguatannya dalam Sistem Pendidikan Nasional
}

\author{
Miftahul Huda1, Rhoni Rodin ${ }^{2}$ \\ 1Universitas Nahdlatul Ulama Cirebon, Indonesia \\ 2Institut Agama Islam Negeri Curup, Indonesia
}

\begin{abstract}
Keywords:
Islamic Education, Indonesia, National Education System
\end{abstract}

*Correspondence Address: miftahul1991@gmail.com

\begin{abstract}
This paper aims to analyze the development of Islamic education in Indonesia and efforts to strengthen it in the national education system. This type of research is descriptive qualitative. Study of literature by focusing on terms of peeling, summarizing and collecting a literature, then the authors provide an analysis of the data that has been collected. The results showed that during the pre-independence era religious education was not only not recognized but also not included in the education system, it was even suspected of being a place to incite and fight the invaders. At the time of independence it did not yet have a role because the government still tended to be controlled by nationalist and secular groups, if there were Islamic groups, Islam was still more abangan. Thus the New Order government continuously fostered the quality of madrasa education so that in 1975 a joint decree (SKB) was issued by three ministers on Improving the Quality of Education in Madrasas, where the SKB of the three ministers had advantages and disadvantages. So that the solution of this weakness is the government is trying to make breakthroughs to restore the function of the madrasa as a place to print religious leaders, namely by opening an alternative Madrasah Aliyah named Madrasah Aliyah Special Program (MAPK). Henceforth, this MAPK was changed to Madrasah Aliyah Religious (MAK) which focuses and strengthens the field of Islamic education. There are two strengthening of Islamic education in the national education system, namely strengthening Islamic educational institutions, and strengthening religious subjects in all schools both under the auspices of the Ministry of Religion and other Ministries.
\end{abstract}

\section{PENDAHULUAN}

Agenda permasalahan universal yang dihadapi manusia dewasa ini, yang paling menarik untuk dibahas adalah pendidikan. Pendidikanlah yang selama ini dan juga senantiasa paling bertanggung jawab untuk pengembangan peradaban manusia. Ketika mencermati pada tataran lingkup yang lebih sempit, dalam skala nasional, lebih kurang 27 juta penduduk Indonesia, masih berkubang dalam kemiskinan. Problematika ini menunjukan bahwa Indonesia merupakan pusat konsentrasi umat
Islam yang terbesar di dunia. Dengan demikian problematika yang dihadapi Bangsa Indonesia adalah masalah umat Islam juga. Sehingga dengan demikian dapat dipahami bahwa masalah pendidikan di Indonesia sebenarnya juga masalah yang dihadapi oleh pendidikan Islam.

Dalam konteks pendidikan Islam di Indonesia, sampai saat ini masih terlihat secara jelas bahwa eksistensi madrasah belum menempati posisi yang strategis dalam sistem pendidikan nasional. Penyerahan pengelolaannya di bawah Departemen Agama (sekarang 
Kementerian Agama) agaknya sematamata atas pertimbangan ini. Usahausaha penegerian dan menyusun kurikulum sejauh ini tampaknya belum dapat dijadikan alasan untuk mengakui lembaga ini sebagai bagian penting dari sistem pendidikan nasional. Namun demikian, jika berpegang pada undangundang dan ketentuan yang ada, mengintegrasikan madrasah ke dalam sistem pendidikan nasional juga tidak sepenuhnya menguntungkan umat Islam. Dengan menjadi bagian dari sistem pendidikan nasional madrasah memang akan mendapatkan status yang sama dengan sekolah, tetapi dengan status ini terdapat akibat bahwa madrasah itu harus dikelola oleh Departemen Pendidikan dan Kebudayaan (sekarang Kemendikbud) yang merupakan satu-satunya lembaga pemerintah yang bertanggung jawab dalam penyelenggaraan pendidikan umum dan kejuruan. Hal yang terakhir ini tidak disetujui oleh umat Islam yang lebih menghendaki pengelolaan madrasah itu di bawah Kementerian Agama. ${ }^{1}$

Hal ini diperkuat oleh Muhaimin bahwa Sementara, di Indonesia diilihat dari sejarahnya setidak-tidaknya ada dua faktor penting yang melatarbelakangi kemunculan madrasah, yaitu: pertama, adanya pandangan yang mengatakan bahwa sistem pendidikan Islam tradisional dirasakan kurang bisa memenuhi kebutuhan pragmatis masyarakat; kedua, adanya kekhawatiran atas cepatnya perkembangan persekolahan Belanda yang akan menimbulkan perkembangan sekularisme, maka masyarakat Muslimterutama para reformis berusaha

\footnotetext{
${ }^{1}$ Maksum, Madrasah: sejarah dan perkembangannya (Jakarta: Logos, 1999), 147.

2 Muhaimin, Pengembangan Kurikulum Pendidikan Agama Islam di sekolah, Madrasah dan Perguruan Tinggi (Jakarta: PT Raja Grafindo Persada, 2005), 45.
}

melakukan pengembangan pendidikan dan pemberdayaan madrasah. ${ }^{2}$

Pendidikan di Indonesia selama ini berjalan secara dualisme pendidikan (Umum dan agama), terjadi pemissahan antara ilmu umum dan ilmu agama. Hal ini terjadi sejak pemerintahan kolonial Balanda memperkenalkan sistem pendidikan yang bersifat sekuler, sementara pendidikan Islam yang diwakili oleh pesantren tidak memperhatikan pengetahuan umum, sampai Indonesia merdeka, meskipun pada awal kemrdekaan masih mewarisi sistem pendidikan yang bersifat dualistis.

Pendidikan Islam di Indonesia dalam sejarah penjangnya, mulai pada masa penajajahan sampai Indonesia merdeka menghadapi berbagai persoalan dan kesenjangan dalam berbagai aspek, berupa persoalan dikotomi pendidikan, kurikulum, tujuan, sumber daya, serta manajemen pendidikan Islam. Sehingga Azra mengatakan bahwa pendidikan Islam sebagaimana terlihat dalampenyusunan Undang-Undang Sistem Pendidikan Nasional tahun 2003, walaupun ada sebagian pasalnya yang belum direalisasikan secara konsisten oleh pemerintah, contohnya Pasal 49 ayat 12 tentang anggaran pendidikan. ${ }^{3}$

Sementara Sanaky mengatakan, upaya pemerintah untuk memperbaiki pendidikan Islam di Indonesia dapat kita lihat komitmen mereka dalam penyusunan UU Sisdiknas 2003, walaupun perbaikannya belum dilakukan secara mendasar, sehingga terkesan seadanya saja. Usaha pembaharuan dan peningkatan pendidikan Islam sering bersifat

\footnotetext{
3 Azra, A. Pendidikan Islam: Tradisi dan Modernisasi Menuju Milenium Baru (Jakarta: Logo Wacana Ilmu, 1999), 149.
} 
sepotong-sepotong atau tidak komprehensif dan menyeluruh serta sebagian besar sistem dan lembaga pendidikan Islam belum dikelola secara professional. $^{4}$

Keberadaan sistem pendidikan Islam Indonesia dihadapkan pada berbagai persoalan, antara lain: pengakuan lulusan yang dihasilkan oleh madrasah sebagai sistem pendidikan Islam sampai pada persoalan tata kelola madrasah yang terkesan semrawut. Sementara itu, perkembangan yang terjadi dalam kehidupan sosial, memaksa madrasah harus tetap eksis tanpa harus mengorbankan nilai-nilai yang telah dirintis oleh para ulama sebagai pendiri madrasah. Dalam suasana yang demikian tentu madrasah harus mengubah paradigma sebagai lembaga pendidikan yang "liar" sebagaimana label tersebut pernah diberikan oleh Pemerintah Kolonial Belanda menjadi lembaga pendidikan yang mengikuti kebijakan pemerintah Indonesia dalam meningkatkan mutu pendidikan secara nasional. Karena bagaimanapun juga sistem pendidikan Islam Indonesia telah menjadi bagian dari Sistem Pendidikan Nasional dan NKRI (Negara Kesatuan Republik Indonesia). ${ }^{5}$

Sementara Ismail dalam penelitiannya menyimpulkan bahwa ada beberapa implikasi akibat kebijakan-kebijakan politik pendidikan yang dilakukan oleh pemerintah yang berkuasa pada saat itu terhadap pendidikan Islam. Dimulai dari pra kemerdekaan, pasca kemerdekaan meliputi orde lama, orde baru, dan orde reformasi seperti sekarang ini), dimana kesemua kebijakan politik pendidikan

4 Sanaky, H. Paradigma Pendidikan Islam (Yogyakarta: Safiria Insania Press, 2004), 86.

5 Fitriani, "Problematika Pendidikan Islam sebagai Sub Sistem Pendidikan Nasional di Era Global." Jurnal at-Tahrir, Vol. 11 No. 2, (2011), 305. tersebut membawa implikasi yang serius terhadap perkembangan pendidikan Islam di Indonesia. misalnya, implikasi kebijakan politik pendidikan madrasah pada aspek manajemen madrasah di Indonesia berupa: (1) madrasah gamang merespon kebijakan otonomisasi pendidikan dan perimbangan keuangan pusat-daerah. (2) Terjadinya ketidakseimbangan kebijakan pendidikan madrasah menyebabkan jurang kesenjangan dan ketimpanganpengelolaan antara lembaga pendidikan umum dengan madrasah. (3) Pengelolaan madrasah menjadi tanggungjawab Departemen Agama semata-mata. (4) Pemerintah daerah kurang peduli terhadap madrasah karena dalam UU No. 32/2004 tentang Pemerintahan Daerah pasal 7 (1) secara tersirat digambarkan bahwa madrasah adalah bagian dari urusan "agama" yang merupakan salah satu urusan wajib pemerintah pusat yang kewenangannya tidak diserahkan kepada pemerintah daerah. Departemen Agama tidak bisa optimal dalam upaya memperbaiki mutu madrasah. ${ }^{6}$

Berdasarkan penjelasan di atas, pada dasarnya penelitian ini bertujuan melakukan analisis kritis terhadap regulasi pendidikan Islam yang tercermin dalam Sistem Pendidikan Nasional. Sebagaimana dijelaskan di atas, masih banyak kebijakan-kebijakan pendidikan nasional yang tertuang dalam undang-undang sistem pendidikan Nasional yang belum memihak kepada pendidikan Islam. Hal ini tentunya harus dikaji secara bersama sehingga akan ditemukan

\footnotetext{
6 Ismail. "Politik pendidikan madrasah di indonesia pasca kemerdekaan: 1945-2003". Jurnal Ta'dib, Vol. XV No. 02, (2010): 170.
} 
solusi konstruktif dalam rangka pengembangan pendidikan Islam di Indonesia.

\section{METODE PENELITIAN}

Penelitian ini menggunakan pendekatan kualitatif dengan analisis deskriptif. Teknik pengumpulan data dilakukan dengan kajian pustaka/ studi literatur yang berkaitan dengan pendidikan Islam di Indonesia. Dengan kata lain, istilah Studi Literatur ini juga sangat familiar dengan sebutan studi pustaka. Ada beberapa metode yang dapat dilakukan untuk melakukan Studi Literatur, seperti mengupas (criticize), membandingkan (compare), meringkas (summarize), dan mengumpulkan (synthesize) suatu literatur. Dengan demikian, metode yang digunakan dalam tulisan ini yaitu studi literatur dengan menitikberatkan pada segi mengupas, meringkas dan mengumpulkan suatu literatur, kemudian diberikan analisis terhadap data yang telah dikumpulkan.

\section{HASIL DAN PEMBAHASAN \\ Perkembangan Pendidikan Islam di Indonesia}

Setelah Indonesia merdeka, umat Islam semakin menyadari pentingnya perjuangan Umat Islam dalam meraih kemerdekaan, dan pemerintah berusaha melakukan memperbaiki pendidikan Islam di Indonesia, dan Sebagai realisasinya Pemerintah Indonesia telah merumuskan dalam undang-undang Republik Indonesia No. 2 Tahun 1989 tentang sistem pendidikan Nasional yang diteruskan dengan UU No. 20 Tahun 2003 yang mengatur penyelenggaraan satu sistem Pendidikan nasional, sebagai upaya pengintegrasian pendidikan Islam dalam sistem pendidikan Nasional, maka dalam makalah ini akan membahas tentang Pendidikan Agama
Islam dalam sistem pendidikan Nasional.

Pendidikan Islam (pelajaran agama) telah diajarkan di sekolahsekolah negeri sejak Indonesia merdeka tahun 1945. Pada masa kabinet RI pertama tahun 1945, Menteri Pendidikan, Pengajaran dan Kebudayaan yang pertama Ki Hajar Dewantara telah mengirimkan surat edaran ke daerah-daerah yang isinya menyatakan bahwa pelajaran budi pekerti yang telah ada pada masa penjajahan Jepang tetap diperkenankan dan diganti namanya menjadi pelajaran Agama. Pada saat tersebut, pendidikan agama belum wajib diberikan pada sekolah-sekolah umum, namun bersifat sukarela/fakultatif, dan tidak menjadi penentu kenaikan/kelulusan peserta didik.

Pendidikan Islam berstatus mata pelajaran pokok di sekolah-sekolah umum mulai SD sampai dengan Perguruan Tinggi berdasarkan TAP MPRS nomor XXVII/MPRS/1966 Bab I Pasal I yang berbunyi: "Menetapkan pendidikan agama menjadi mata pelajaran di sekolah-sekolah mulai dari Sekolah Dasar sampai dengan Universitas-Universitas Negeri". Peraturan ini keluar dengan tanpa protes, setelah penumpasan PKI.

Pelaksanaan Pendidikan Islam pada umumnya serta Pendidikan Agama Islam pada khususnya di sekolahsekolah umum tersebut semakin kokoh oleh berbagai terbitnya perundangundangan selanjutnya, hingga lahirnya Undang-Undang Nomor 20 tahun 2003 tentang Sistem Pendidikan Nasional yang lebih menjamin pemenuhan pendidikan agama kepada peserta didik. Dan diikuti dengan lahirnya peraturanperaturan selanjutnya sampai dengan terbitnya Peraturan Menteri Agama RI 
No. 16 Tahun 2010 tentang Pengelolaan Pendidikan Agama Pada Sekolah. ${ }^{7}$

Dengan makin kuatnya posisi Pendidikan Islam di dalam sistem pendidikan Indonesia setelah mengalami masa pergulatan yang sangat panjang, tentunya secara ideal telah menunjukkan hasil yang signifikan dan tujuan pendidikan agama Islam telah tercapai yaitu pendidikan jasmani, pendidikan akal dan pendidikan akhlak. ${ }^{8}$ Namun di dalam kenyataan di lapangan, banyak sekali problematika yang muncul sehingga berakibat tidak maksimalnya pendidikan Agama Islam di sekolah, baik di tingkat SD, SMP, SMA dan SMK.

Jika kembali kepada sejarah perkembangan pendidikan Islam di Indonesia, terutama dalam konteks mengintegrasikan pendidikan dalam sistem pendidikan nasional, Surat Keputusan Bersama (SKB) Tiga menteri merupakan regulasi yang bisa merintis penguatan posisi pendidikan Islam secara nasional. Surat Keputusan Bersama tiga menteri tersebut ditandatanganioleh tiga orang menteri, yaitu Menteri Agama, Menteri Pendidikan dan Kebudayaan, serta Menteri Dalam Negeri. Nomor 6 Tahun 1975, Nomor 037/ U/ 1975, dan Nomor 36 Tahun 1975 tentang Peningkatan Mutu Pendidikan Pada Madrasah. SKB tiga Menteri ini ditandatangani di Jakarta oleh 3 orang menteri, yaitu: Dr. H. A. Mukti Ali (Menteri Agama), Dr. Syarief Thajeb (Menteri Pendidikan dan Kebudayaan), dan H. Amir Machmud (Menteri Dalam Negeri) pada tanggal 24 Maret 1975.9

Surat Keputusan Bersama (SKB) tersebut berlaku untuk madrasah dan

\footnotetext{
7 Soebahar, A. H. Kebijakan Pendidikan Islam: Dari Ordinasi Guru sampai UU Sisdiknas (Jakarta: Rajawali Pers, 2013), 116.

8 Salim, M. H. Studi Ilmu Pendidikan Islam (Yogyakarta: Ar-Ruzz Media2012), 65
}

semua jenjang baik negeri maupun swasta, baik madrasah dalam lingkungan pondok pesantren maupun di luar pondok. SKB tersebut bertujuan untuk meningkatkan mutu pendidikan madrasah agar sejajar dengan sekolah umum. Kesejajaran tersebut meliputi: (1). Ijazah madrasah dapat mempunyai nilai yang sama dengan ijazah sekolah umum; (2). Lulusan madrasah dapat melanjutkan ke sekolah umum setingkat lebih tinggi. (3). Siswa madrasah dapat pindah ke sekolah umum yang sama tingkatannya. Hal tersebut ditegaskan lagi dengan merinci bagian-bagian yang menunjukkan kesetaraan madrasah dengan sekolah. Dalam Bab I pasal 1, ayat 2 misalnya dinyatakan: Madrasah itu meliputi tiga tingkatan: (1) Madrasah Ibtidaiyah, setingkat dengan Sekolah Dasar; (2) Madrasah Tsanawiyah, setingkat dengan Sekolah Menengah Pertama; (3) Madrasah Aliyah, setingkat dengan Sekolah Menengah Atas.10 Selanjutnya dalam Bab II pasal 2 ayat a, b, dan c disebutkan bahwa:

Ayat a: Ijazah madrasah dapat mempunyai nilai yang sama dengan ijazah sekolah Umum yang setingkat.

Ayat b: Lulusan madrasah dapat melanjutkan kesekolah umum setingkat lebih atas.

Ayat c: Siswa madrasah dapat berpindah kesekolah umum yang setingkat. ${ }^{11}$

Mengenai pengelolaan dan pembinaan dinyatakan dalam Bab IV pasal 4 sebagai berikut: (1) Pengelolaan madrasah dilakukan oleh Menteri Agama. (2) Pembinaan mata pelajaran

\footnotetext{
${ }^{9}$ Soebahar, Kebijakan Pendidikan Islam, 116.

${ }^{10}$ Soebahar, 117.

${ }^{11}$ Soebahar, 118.
} 
agama pada madrasah dilakukan oleh Menteri Agama. (3) Pembinaan dan pengawasan mutu mata pelajaran umum pada madrasah dilakukan oleh Menteri Pendidikan dan Kebudayaan, bersama-sama dengan Menteri Agama dan Menteri Dalam Negeri.

SKB Tiga Menteri ini dapat dipandang sebagai pengakuan yang lebih nyata terhadap eksistensi madrasah dan sekaligus merupakan langkah strategis menuju tahapan integrasi madrasah ke dalam Sistem Pendidikan Nasional yang tuntas. Dengan SKB tersebut madrasah memperoleh definisinya yang semakin jelas sebagai lembaga pendidikan yang setara dengan sekolah sekalipun pengelolaannya tetap berada pada Departemen Agama. ${ }^{12}$ Dalam hal ini, madrasah tidak lagi hanya dipandang sebagai lembaga pendidikan keagamaan atau lembaga penyelenggara kewajiban belajar, tetapi sudah merupakan lembaga pendidikan yang menjadikan mata pelajaran agama Islam sebagai mata pelajaran dasar yang sekurang- kurangnya 30\%, di samping mata pelajaran umum. Namun oleh Menteri Agama pada saat itu, Mukti Ali, dijelaskan dalam prakteknya kedua mata pelajaran tersebut dapat saling mengisi, sehingga sama-sama $100 \%$.

Dengan SKB Tiga Menteri, Departemen Agama melakukan usaha pemantapan struktur madrasah secara lebih komprehensif. Sejumlah keputusan dikeluarkan untuk mengatur organisasi dan tata kerja madrasah pada semua tingkatan. Departemen Agama juga mengeluarkan peraturan tentang persamaan ijazah madrasah swasta dengan madrasah negeri. Dalam hal kurikulum dilakukan penyusunan ulang

12 Soprayani. "Madrasah dan Pemberdayaan Peran Masyarakat". Jurnal Darussalam, Vol. 11, No.2, 2010, 130. dengan menyempurnakan komposisi mata-mata pelajaran umum. Sejalan dengan SKB Tiga Menteri itu, kurikulum madrasah memuat mata-mata pelajaran umum dalam jumlah yang sama dengan kurikulum sekolah pada tiap-tiap jenjangnya. Madrasah dengan demikian dapat dikatakan sebagai sekolah plus agama. ${ }^{13}$

Pengakuan terhadap status madrasah, yang diikuti dengan penyesuaian-penyesuaian dengan sistem sekolah telah membuahkan respon yang menyenangkan. Diantaranya, diperolehnya Inpres untuk seribu madrasah pada tahun 1978 dan beberapa tahun kemudian datang permintaan dari Rektor IPB, Prof. Dr. Andi Hakim Nasution untuk mengirimkan beberapa lulusan terbaik Madrasah Aliyah sebagai mahasiswa PMDK di IPB.

Madrasah Aliah Program Khusus (MAPK) merupakan antisipasi terhadap menurunnya kemampuan bidang agama pada lulusan Madrasah Aliyah setelah mereka berubah menjadi madrasah dengan beban kurikulum $70 \%$ umum dan 30\% agama (SKB 3 Menteri 1975). Apalagi setelah UU Sisdiknas No. 2 Tahun 1989 yang menyamakan kurikulum sekolah dengan madrasah, yang membedakan hanya jumlah jam pelajaran agama yang menjadi ciri khas. Pada tingkat SD, SMP, SMA pelajaran agama 2 jam, maka pada MI menjadi 4 sampai dengan 7 jam dan pada MTs dan MA menjadi 9 jam. ${ }^{14}$

Di sisi lain kekhawatiran masyarakat terhadap akan makin berkurangnya para ahli agama (kyai/ulama) menjadi alasan utama dibukanya MAPK. Melalui SKB ini memang status madrasah disamakan

\footnotetext{
13 Maksum, Madrasah: Sejarah dan Perkembangannya (Jakarta: Logos, 1999), 150.

14 Rahim, H. Madrasah dalam Politik Pendidikan di Indonesia (Jakarta: Logos, 2005), 176.
} 
dengan sekolah berikut jenjangnya: MI sejajar dengan SD, MTs sejajar dengan SMP, dan MA sejajar dengan SMA. Dengan SKB 3 Menteri ini pula alumni MA dapat melanjutkan ke universitas umum, dan begitu pula sebaliknya, alumni SMA dapat melanjutkan studinya ke IAIN/UIN. Karena madrasah diakui sejajar dengan sekolah umum, kurikulum madrasah harus sama dengan sekolah, berisi mata-mata pelajaran dengan perbandingan $70 \%$ mata pelajaran umum dan $30 \%$ pelajaran agama. ${ }^{15}$

Efek penyamaan kurikulum ini adalah bertambahnya beban yang harus dipikul oleh madrasah. Disatu pihak ia harus memperbaiki mutu pendidikan umumnya setaraf dengan standar yang berlaku di sekolah. Di lain pihak, bagaimana pun juga madrasah sebagai lembaga pendidikan Islam harus menjaga agar mutu pendidikan agamanya tetap baik. Namun, dengan penguasaan ilmu-ilmu agama hanya $30 \%$ termasuk bahasa Arab,tidak cukup memadai bagi alumni MA untuk memasuki IAIN/UIN, apalagi menjadi calon- calon ulama.

Fakta inilah yang membuat Munhawir Sadzali, ketika menjabat Menteri Agama (1983-1993), mencari solusi terhadap apa yang disebutnya "krisis ulama", yaitu dengan membuka Madrasah Aliyah alternatif yang diberi nama Madrasah Aliyah Program Khusus (MAPK) dengan komposisi kurikulum $70 \%$ pelajaran agama dan $30 \%$ pelajaran umum plus pengajaran bahasa (Arab dan Inggris) secara intensif. Hingga Dengan program ini input IAIN secara kualitatif dapat ditingkatkan, dan yang penting lagi

15 Rahim, 177.

16 Rahim, 178.

17 Hasbullah, Sejarah Pendidikan Islam di Indonesia: Lintasan Sejarah Pertumbuhan dan Perkembangan. (Jakarta: LSIK, 1996), menjadi pendukung bagi kemunculan calon-calon ulama. ${ }^{16}$

Pada perjalanannya, MAPK ini kemudian berubah menjadi MAK (Madrasah Aliyah Keagamaan) berdasarkan Keputusan Menteri Agama No.73 Tahun 1987. Madrasah ini menitik beratkan pada pengembangan dan pendalaman ilmu-ilmu agama dengan tidak mengesampingkan pengetahuan umum sebagai usaha pengembangan wawasan. Untukitu, dilakukan studi kelayakan untuk menentukan madrasah mana yang dianggap paling memungkinkan untuk ditunjuk sebagai pelaksana program ini. Akhirnya, ditetapkan 5 MadrasahAliyah Negeri sebagai penyelenggara, yaitu MAN Darussalam Ciamis Jawa Barat, MAN Ujung Pandang (sekarang Makasar), MAN1 Yogyakarta, MAN Kota Baru Padang Panjang Sumatra Barat, dan MAN Jember Jawa Timur. Hingga tahun 1993 program ini telah berjumlah 16 MAN dan 105 MAS. ${ }^{17}$

Tujuan utama dibukanya MAPK ini adalah: (1). Untuk memenuhi kebutuhan tenaga ahli dibidang agama Islam sesuai dengan tuntutan pembangunan nasional dalam rangka peningkatan mutu pendidikan pada Madrasah Aliyah; (2). Untuk menyiapkan lulusan agar memiliki kemampuan dasar yang diperlukan bagi pengembangan diri sebagai ulama yang intelek; (3). Menyiapkan lulusan sebagai calon mahasiswa IAIN/UIN atau PTAI lainnya termasuk calon mahasiswa Universitas Al-Azhar Mesir. ${ }^{18}$

$$
\text { Penyelenggaraan }
$$

MAPK melibatkan instansi Pusat daerah secara terpadu dalam suatu tim sendiri. Caloncalon siswa yang akan diterima di MAPK

\footnotetext{
18 Rahim, Madrasah Dalam Politik Pendidikan di
} Indonesia, 179. 
tidak sembarangan siswa, tetapi harus memenuhi syarat-syarat yang ditentukan dan melalui seleksi yang ketat. Bahkan menurut catatan Direktorat Pendidikan Madrasah, untuk tahun 2017 ini sebanyak 432 (empat ratus tiga puluh dua) orang akan diterima menjadi murid MAN PK. Ke432 murid MAN PK tersebut tersebar di 10 (sepuluh) propinsi se-Indonesia, yaitu: (1) MAN 1 Jember-Jawa Timur (48 murid); (2) MAN Koto Baru Padang Panjang-Sumatera Barat (48 murid); 3) MAN 3 Makasar-Sulawesi Selatan (48 murid); (4) MAN 1 Surakarta-Jawa Tengah (48 murid); (5) MAN 1 Darussalam Ciamis-Jawa Barat (48 murid); (6) MAN 2 Mataram-NTB (24 murid); (7) MAN 1 Yogyakarta-DIY (24 murid); (8) MAN Denanyar JombangJawa Timur (48 murid); (9) MAN 2 Samarinda-Kalimantan Timur (48 murid); dan (10) MAN 2 MartapuraKalimantan Selatan (48 murid). ${ }^{19}$

Berdasarkan penjelasan di atas, dapat dipahami bahwa SKB tiga menteri merupakan puncak usaha pemerintah dalam mengatasi ketimpangan antara sekolah-sekolah agama (madrasah) dengan sekolah-sekolah umum untuk menuju ke kesatuan sistem pendidikan nasional. Dengan SKB ini telah tercapai integrasi antara pendidikan agama dan pendidikan umum ke dalam sistem pendidikan nasional. ${ }^{20}$ Dengan demikian, berarti bahwa pendidikan Islam tidak dapat dipisahkan dengan pendidikan nasional. Pendidikan Islam telah menjadi bagian integral yang tak terpisahkan dari pendidikan nasional.

Secara tidak langsung, implikasi kebijakan ini memberi peluang bagi lulusan madrasah untuk melakukan

19 Admin. (2017). Madrasah Aliyah Keagamaan Terbuka untuk Umum. Retrieved 2020, from http://www.pendis.kemenag.go.id/index.php?a=deti lberita\&id $=8531$.

20 Asrohah, H. Sejarah Pendidikan Islam (Jakarta: Logos, 1999), 110. mobilitas sosial dan vertikal yang selama ini terbatas pada lembagalembaga pendidikan tradisional seperti pesantren dan madrasah. Disisi lain hal ini membuka peluang kemungkinan lulusan madrasah untuk memasuki wilayah pekerjaan pada sektor modern. ${ }^{21}$

Kemunculan SKB Tiga Menteri ini memiliki kelebihanya itu, sebagai upaya modernisasi madrasah untuk mampu menyejajarkan mutu pendidikannya dengan sekolah umum sederajat. Namun, di sisi lain SKB Tiga Menteri ini memiliki kelemahan yaitu, mampu memberhentikan kerja mesin madrasah dalam melahirkan lulusan yang bermutu ulama. Solusi dari kelemahan ini pemerintah berusaha mengadakan terobosan-terobosan

untuk mengembalikan fungsi madrasah sebagai tempat mencetak para pemimpin agama yaitu dengan membuka Madrasah Aliyah alternatif yang diberi nama Madrasah Aliyah Program Khusus (MAPK). Ini merupakan sebuah inovasi dalam pendidikan Islam karena siswa yang diterima di MAPK bukan siswa yang sembarangan tetapi siswa yang terpilih melalui seleksi yang ketat. Siswa yang diterima di madrasah ini (terutama program Keagamaan) wajib tinggal diasrama dan diberikan tambahan pelajaran pada sore hari serta menggunakan bahasa Arab dan Inggris sebagai bahasa sehari-hari di asrama. Buku tes/pelajaran pokok yang digunakan adalah kitab-kitab berbahasa Arab. Dilihat dari sini, kehadiran MAPK hakikatnya adalah bentuk respon positif progresif madrasah terhadap tantangan yang dihadapi.

21 Supiana, Sistem pendidikan madrasah unggulan di MAN Insan Cendikia, MAN 1 Bandung, dan MAN Darussalam Ciamis (Jakarta: Badan Litbang dan Diklat Departemen Agama RI, 2008), 44. 
Pada kurikulum 1976 yang disempurnakan lagi melalui kurikulum 1984 sebagaimana yang dinyatakan dalam SK Menteri Agama No.45 Tahun 1987, memiliki tiga keistimewaan di banding kurikulum sebelumnya. Pertama, komposisi kurikulum 1976, dengan $70 \%$ mata pelajaran umum, menunjukkan bahwa kurikulum ini adalah "lebih sekuler" dari yang sebelumnya. Kedua, terdapat keseragaman kurikulum disebagian besar madrasah diseluruh Indonesia menunjukkan bahwa ada standar yang jelas untuk prestasi akademik pendidikan madrasah. Keseragaman ini, dapat dipahami sebagai dari dukungan pemerintah untuk modernisasi madrasah dan intervensi politik pada madrasah swasta. Ketiga, jumlah mata pelajaran yang diajarkan menunjukkan bahwa kurikulum tahun 1976 disederhanakan dibandingkan dengan yang sebelumnya. Jumlah mata pelajaran yang ditawarkan dalam kurikulum madrasah ibtidaiyah, misalnya, berkurang dari 18 mata pelajaran dikurikulum tahun 1973 menjadi 13 mata pelajaran dikurikulum tahun 1976, sedangkan jumlah waktu yang sama dialokasikan setiap minggu untuk belajar. Demikian juga, kurikulum madrasah tsanawiyah dan madrasah aliyah berkurang dari masing-masing 23 mata pelajaran menjadi 16 mata pelajaran untuk madrasah tsanawiyah dan 19 mata pelajaran untuk madrasah aliyah. $^{22}$

Yahya menyebutkan bahwa Madrasah merupakan lembaga pendidikan Islam yang mempunyai

22 Zuhdi, M. Political and Social Influences on Religious School: a Historical Perspective on Indonesian Islamic School Curricula (Canada: McGill University, 2006). 123.

23 Yahya, M. D. "Posisi Madrasah dalam Sistem Pendidikan Nasional di Era Otonomi Daerah". Jurnal Khazanah, Vol. XII No. 1, (2014): 81. sejarah perjalanan panjang, sampai akhirnya diakui bagian dari Sistem Pendidikan Nasional. Keberadaan madrasah yang sudah sangat lama di kelola oleh Depag/Kemenag melalui sektor agamamenjadi problem tatkala dihadapkan dengan UU otonomi daerah yang meniscayakan sektor pendidikan diserahkan pengelolaannya pada Pemerintah Daerah. Pada akhirnya kemajuan madrasah bukan terletak pada berada di bawah Kemenag ataupun Kemendiknas tapi pada kreativitas madrasah itu sendiri. ${ }^{23}$

Nursikin dalam penelitiannya menyimpulkan bahwa memantapkan eksistensi madrasah dan sekolah Islam untuk memenuhi tiga tuntutan minimal dalam peningkatan kualitas madrasah dan sekolah Islam, yaitu: (1) menjadikan madrasah dan sekolah Islam sebagai tempat untuk membina ruh atau praktik hidup ke-Islaman, (2) memperkokoh keberadaan madrasah dan sekolah Islam sehingga sederajat dengan sistem sekolah, (3) madrasah dan sekolah Islam harus dapat merespons tuntutan masa depan guna mengantisipasi perkembangan iptek dan era globalisasi. ${ }^{24}$

Pelajaran umum dari madrasah dan sekolah Islam mencapai tingkat yang sama dengan tingkat mata pelajaran umum disekolah umum yang setingkat". Ditetapkan pula bahwa dengan tercapainya tingkat mata pelajaran umum pada madrasah dan sekolah Islam yang sama dengan mata pelajaran pada sekolah-sekolah umum tersebut, maka sekolah dan madrasah dan sekolah Islam diakui mempunyai

24 M. Nursikin, "Eksistensi Madrasah dan Sekolah Islam sebagai Lembaga Pendidikan Islam dalam Sistem Pendidikan Nasional: Studi Kasus di MAN Yogyakarta III dan SMA Muhammdiyah 1 Yogyakarta. Jurnal Istawa: Jurnal Pendidikan Islam, Vol. 3 No. 1, 2018, 48. 
kedudukan yang sama, sehingga: (1) Ijazah madrasah dan sekolah Islam dapat mempunyai nilai yang sama dengan ijazah sekolah umum yang setingkat, (2) Lulusan madrasah dan sekolah Islam dapat melanjutkan kesekolah umum setingkat lebih tinggi, dan (3) Siswa madrasah dan sekolah Islam dapat berpindah ke sekolah umum yang setingkat. ${ }^{25}$

Dengan demikian secara berangsur-angsur madrasah dan sekolah Islam (termasuk Madrasah Aliyah) diintegrasikan ke dalam Sistem Pendidikan Nasional. Puncaknya adalah lahirnya kebijakan Undang-Undang tentang Sistem Pendidikan Nasional (UUSPN) Nomor 2 tahun 1989 yang memperkuat SKB tersebut. Bahkan dalam kebijakan UUSPN tersebut secara tegas disebutkan bahwa madrasah (termasuk MA/sekolah Islam) adalah sekolah umum yang berciri khas agama Islam. Kemudian diperkuat oleh Undang-undang Sistem Pendidikan Nasional No 20 Tahun 2003.

Awwaliyah dan Baharun dalam penelitiannya menyimpulkan bahwa melihat realita pada saat sekarang, yakni semakin kendurnya nilai-nilai keIslaman dan adat ketimuran yang sebenarnya menjadi jati diri dari Negara kita ini,merupakan sebuah bukti konkrit gagalnya Pendidikan Islam sebagai sistem pendidikan nasional. Jika ditelaah lebih dalam lagi terdapat beberapa problematika yang sangat perlu kiranya untuk ditanggulangi. Untuk menanggulangi problematika tersebut Negara kemudian memberi ruang kepada Pendidikan Islam dengan menetapkan didalam Undang Undang Sitem Pendidikan Nasional

\footnotetext{
${ }^{25}$ Nursikin, Eksistensi Madrasah, 49.

26 R. A. Baharun, "Pendidikan Islam dalam Sistem Pendidikan Nasional: Telaah Epistemologi terhadap Problematika Pendidikan Islam". Jurnal Ilmiah Didaktika, Vol. 19 No. 1, 2018, 39.
}

bahwasannya Pendidikan Islam memiliki wewenang yang lebih luas untuk berkontribusi dalam mengarahkan manusia kearah yang dicita-citakan. ${ }^{26}$

Lebih lanjut Samrin bahwa berbagai krisis multidimensional yang melanda Indonesia tidak bisa dilihat dan diatasi dari pendekatan mono dimensional. Pangkal krisis tersebut disebabkan rendahnya moral, dan akhlak manusia, maka pendidikan Islam memiliki andil yang sangat besar dalam membangun watak dan peradaban bangsa yang bermartabat. ${ }^{27}$

Masykur memperkuat pernyataan di atas bahwa Pendidikan agama Islam sebagai mata pelajaran dan nilai belum mampu memberikan pemahaman dasar yang menghasilkan sikap laten sehingga dapat berfikir, bersikap dan berperilaku sesuai nilai-nilai tauhid, kemanusiaan, keseimbangan dan nilai rahmatan lil alamin belum dapat ditanamkan dalam kepribadian siswa. Kegagalan inilah yang kemudian para pakar mengatakan terjadinya kebobrokan dan rusaknya mental bangsa, kondisi ini cermin dari gagalnya dunia pendidikan dalam menanamkan nilai-nilai lebih khusus lagi kegagalan dunia pendidikan agama. ${ }^{28}$

\section{Upaya Penguatan Pendidikan Islam dalam Sistem Pendidikan Nasional}

Pada Orde Reformasi, keberadaan pendidikan Islam semakin diakui, hal ini dibuktikan dengan diintegrasikannya pendidikan Islam dalam sistem pendidikan nasional. Haidar Putra Daulay menyatakan bahwa setidaknya ada tiga hal yang terkait dengan pendidikan Islam dalam UU No

27 Samrin. "Pendidikan Agama Islam dalam Sistem Pendidikan Nasional di Indonesia”. Jurnal al-Ta'dib, Vol. 8 No. 1, 2015, 106.

28 Masykur, H. Eksistensi dan Fungsi Pendidikan Agama Islam dalam Sistem Pendidikan Nasional. (Skripsi). (Salatiga: FTIK IAIN Salatiga, 2015). 
20/2003, yaitu: Pertama, kelembagaan formal, nonformal, dan informal didudukkannya lembaga madrasah sebagai salah satu lembaga pendidikan formal yang diakui keberadaannya setara dengan lembaga pendidikan sekolah. Kedua, pendidikan Islam sebagai mata pelajaran yaitu pelajaran agama sebagai salah satu mata pelajaran yang wajib diberikan kepada peserta didik di semua jalur, jenis dan jenjang pendidikan. Ketiga, pendidikan Islam sebagai nilai, terdapat seperangkat nilai-nilai islami dalam sistem pendidikan nasional. ${ }^{29}$

Pertama: Pendidikan Islam sebagai Lembaga

1. Lembaga Pendidikan Formal

Pasal 17: Pendidikan dasar berbentuk sekolah dasar (SD) dan Madrasah Ibtidaiyah (MI) atau bentuk lain yang sederajat serta Sekolah Menengah Pertama (SMP) dan Madrasah Tsanawiyah (MTs) atau bentuk lain yang sederajat.

Pasal 18: Pendidikan menengah berbentuk Sekolah Menengah Atas (SMA), Madrasah Aliyah (MA), Sekolah Menengah Kejuruan (SMK), dan Madrasah Aliyah Kejuruan (MAK), atau bentuk lain yang sederajat.

Pasal 20: Pendidikan Tinggi dapat berbentuk Akademi, Politeknik, Sekolah Tinggi, Institut, atau Universitas.

2. Lembaga Pendidikan Nonformal

Pasal 26: Satuan pendidikan nonformal terdiri atas lembaga kursus, lembaga pelatihan, kelompok belajar, pusat kegiatan belajar masyarakat, majelis taklim, serta satuan pendidikan sejenis.

\section{Lembaga Pendidikan Informal}

29 Daulay, H. P. Pendidikan Islam dalam Sistem Pendidikan Nasional di Indonesia (Jakarta: Kencana, 2006), 65.
Pasal 27: Kegiatan pendidikan informal yang dilakukan keluarga dan lingkungan berbentuk kegiatan belajar secara mandiri.

\section{Pendidikan Usia Dini}

Pasal 28: Pendidikan usia dini pada jalur pendidikan formal berbentuk Taman Kanak-kanak (TK), Raudhatul Athfal (RA), atau bentuk lain yang sederajat.

\section{Pendidikan keagamaan}

Pasal 30: Pendidikan keagamaan diselenggarakan oleh pemerintah dan atau kelompok masyarakat dari pemeluk agama sesuai dengan peraturan perundang-undangan. Pendidikan keagamaan berfungsi mempersiapkan peserta didik menjadi anggota masyarakat yang memahami dan mengamalkan nilai-nalai ajaran agamanya dan atau menjadi ahli agama. Pendidikan keagamaan dapat diselenggarakan pada jalur pendidikan formal, nonformal, dan informal. Pendidikan keagamaan berbentuk pendidikan diniyah, pesantren, pasraman, pabhaya samena, dan bentuk lain yang sejenis. ${ }^{30}$

Kedua: Pendidikan Islam Sebagai Mata Pelajaran

Pendidikan Islam sebagai mata pelajaran setidaknya diatur dalam Undang-Undang Sistem Pendidikan Nasional Nomor 20 tahun 2003, yang tertuang dalam beberapa pasal, yaitu:

Pasal 36 ayat 3 menjelaskan bahwa kurikulum disusun sesuai dengan jenjang pendidikan dalam kerangka Negara Kesatuan Republik Indonesia dengan memperhatikan: Peningkatan iman dan taqwa; peningkatan akhlak mulia; peningkatan potensi, kecerdasan, dan minat peserta didik; keragaman potensi daerah dan

\footnotetext{
${ }^{30}$ Undang-Undang No. 20 Tahun 2003 tentang Sistem
} Pendidikan Nasional 
lingkungan; tuntutan pembangunan daerah dan nasional; tuntutan dunia kerja; perkembangan ilmu pengetahuan dan tekhnologi, dan seni; Agama; Dinamika perkembangan global; serta Persatuan nasional dan nilai-nilai kebangsaan. ${ }^{31}$

Di pasal 37 ayat 1, kurikulum pendidikan dasar dan menengah wajib memuat: Pendidikan agama; Pendidikan kewarganegaraan; Bahasa; Matematika; Ilmu pengetahuan alam; Ilmu pengetahuan sosial; Seni dan budaya; Pendidika jasmani dan olahraga; Keterampilan/ kejuruan; dan Muatan lokal.

Di pasal 37 ayat 2, Kurikulum pendidikan tinggi wajib: Pendidikan agama; Pendidikan kewarganegaraan; dan Bahasa.

Pasal 12 ayat a menyebutkan bahwa pendidikan agama adalah hak peserta didik, disebutkan; setiap peserta didik pada setiap satuan pendidikan berhak mendapatkan pendidikan agama sesuai dengan agama yang dianutnya dan diajarkan oleh pendidik yang seagama.

Dalam bagian penjelasan diterangkan pula pendidik dan atau guru agama yang seagama dengan peserta didik difasilitasi dan atau disediakan oleh pemerintah atau pemerintah daerah sesuai dengan kebutuhan satuan pendidikan diatur dalam pasal 41 ayat $3 .^{32}$

Berdasarkan uraian di atas, terlihat dengan jelas bahwa pendidikan Islam telah menempati posisi yang sangat penting dalam sistem pendidikan nasional. Penempatan posisi tersebut terlihat dalam dua hal yaitu pendidikan Islam sebagai lembaga, dan pendidikan Islam sebagai mata pelajaran. Sebagai

\footnotetext{
31 Undang-Undang No. 20 Tahun 2003 tentang Sistem Pendidikan Nasional

32 Hasbullah, Kapita selekta pendidikan, (Jakarta: Rajawali Pers, 1996), 13-16.
}

lembaga, ditandai dengan dibentuknya lembaga pendidikan Islam mulai dari tingkat sekolah dasar (SD) hingga perguruan tinggi. Kemudian sebagai mata pelajaran, sejak SD hingga perguruan tinggi sudah terdapat mata pelajaran Pendidikan Agama Islam.

Secara umum Undang-Undang No. 20 Tahun 2003 terkait pendidikan Islam, secara konseptual telah memberikan landasan kuat dalam mengembangkan dan memberdayakan sistem pendidikan Islam dengan prinsip demokrasi, desentralisasi, pemerataan/ keadilan, mutu dan relevansi, dan menjunjung tinggi hak asasi manusia. Sehingga terwujud akuntabilitas pendidikan yang mandiri menuju keunggulan. Namun meskipun demikian, pemakalah merasa perlu memberikan beberapa catatan tentang proporsional pendidikan Islam di dalam system pendidikan nasional, yaitu:

Pertama, secara struktural lembaga-lembaga pendidikan Islam berada di bawah naungan Depatermen Agama disebabkan karena hambatan stuktural maka dari segi pendanaan terdapat perbedaan antara lembaga pendidikan yang di kelola oleh Depatermen Agama dengan lembaga pendidikan yang di kelola oleh Departemen Pendidikan Nasional sehingga mempengaruhi kualitas SDM, sarana dan prasarana serta kualitas pendidikan secara umum.

Kedua, sistem pengawasan atas implementasi UU Sisdiknas dalam skala nasional dan wilayah terutama terkait pendidikan Islam yang belum mendapat perhatian.

Ketiga, masih labilnya sistem pendidikan nasional. ${ }^{33}$

\footnotetext{
${ }^{33}$ A.K. Huda, Paradigma Pendidikan Islam (Semarang: Pustaka Pelajar, 2001), 87.
} 


\begin{tabular}{llr}
\multicolumn{1}{c}{ Sebagai } & sub-sistem & dalam \\
pendidikan & Nasional, & untuk \\
mmengidentifikasi & berbaga
\end{tabular}
problematika yang dihadapi oleh Pendidikan Islam, tentunya merujuk pada problem-problem pendidikan secara nasional. Pendidikan secara nasional sedikitnya menjalankan empat fungsi: (1) Transmisi kultural, pengetahuan, sikap, nilai, dan norma; (2) Memilih mengajarkan peranan sosial; (3) Menjamin integrasi sosial; (4) Mengadakan inovasi-inovasi sosial.

Berdasarkan fungsi tersebut, terlihat dengan jelas bahwa pendidikan Islam, kendatipun dalam konteks keIndonesiaan merupakan sub-sistem, misi dan perannya tidak jauh berbeda dengan peran Pendidikan nasional tersebut. Untuk menjalankan fungsinya secara efektif dan efisien, suatu sistem pendidikan harus sehat dan terus bergerak sesuai dengan gerak perubahan masyarakat dunia pada umumnya dan Indonesia pada khususnya.

Dalam konteks Pendidikan Islam di negeri ini, terlihat dengan jelas bahwa problem yang dihadapi jauh lebih kompleks dari pada pendidikan umum. Sebagai contoh problem yang paling sederhana, belum memiliki perangkat semacam manual yang dapat dipakai untuk menyelenggarakan Madrasah Diniyyah. Apalagi untuk penataan sistem pendidikan Islam dalam lingkup nasional. Konsekuensi logis dari kenyataan ini antara lain adalah ketidakmampuan pendidikan Islam untuk memenuhi logika persaingan dalam dunia pendidikan secara nasional. Kendatipun oleh umat Islam sendiri kebanyakan lembaga pendidikan Islam dianggap kurang dapat memenuhi kebutuhan, apalagi memenuhi selera mereka. Kalau dicermati, pendidikan Islam yang masih 'kelas dua'dan belum dapat menjadi pendidikan alternatif, antara lain disebabkan beberapa faktor.

Hambatan internal, karena belum tegas filsafat yang mendasarinya, sebagai implikasinya dapat dilihat beberapa gejalanya antara lain: (1) Tiadanya kurikulum yang baku sebagai garis batas terhadap sistem pendidikan lainnya; (2) Belum adanya metodologi yang baku; (3) Belum adanya alat ukur yang dapat diandalkan dalam menilai hasil pendidikan.

Hambatan eksternal antara lain: (1) Masih terlalu tergantung pada pola pendidikan yang digariskan pemerintah, yakni pendidikan untuk menopang pembangunan;

Kekurangan dana dan fasilitas, sehingga pendidikan Islam diorientasikan kepada selera konsumen, dan menyantuni kaum marginal; (3) Masih labilnya sistem pendidikan nasional. ${ }^{34}$

Di sisi lain juga terdapat beberapa hambatan yang bisa menghambat eksistensi Pendidikan Islam secara nasional, diantaranya: Perkembangan kebudayaan dan perubahan masyarakat yang cepat, sehingga pendidikan Islam semakin tidak berdaya berkompetisi dengan laju perubahan masyarakat; (2) Appresiasi masyarakat terhadap lembaga pendidikan Islam yang belum menggembirakan; (3) Adanya pelapisan sosial yang didasarkan pada ukuran serba materialistik dan menyebabkan masyarakat berlomba mnyerbu lembaga pendidikan favorit, dengan tanpa mengindahkan aspek ideologis yang tersembunyi di baliknya; (4)

\footnotetext{
34 Azzahra, R. Pendidikan Islam dalam Sistem Pendidikan Nasional. (Kebumen: PGMI STAINU, tt.), 78.
} 
Adanya kecenderungan mismanajemen, misalnya persaingan ynag tidak sehat antar pimpinan dan kepemimpinan yang tertutup. ${ }^{35}$

Beberapa tahun yang lalu ada problem yang sangat serius bagi alumnus Perguruan Tinggi Islam, dimana mereka tidak bisa mengikuti test CPNS karena dianggap mereka dianggap secara merata sebagai tenaga guru pendidikan Agama Islam, padahal perguruan tinggi Islam telah menghasilkan berbagai alumnus yang berkompeten di bidangnya. Sebagai contoh tadris bahasa Inggris menghasilkan lulusan yang berkompeten sebagai guru mata pelajaran bahasa Inggris di sekolahsekolah baik umum maupun keagamaan. Akan tetapi karena gelar akademik mereka terdapat kata "Islam"nya, misalnya sarjana tadris bahasa Inggris gelar kesarjanaannya S.Pd.I (Sarjana Pendidikan Islam). Gelar ini dianggap mereka hanya membidangi Pendidikan Agama Islam. Namun akhirnya pihak Dirjen Pendidikan Islam menyikapi hal ini secara cepat dan tepat dengan merubah nomenklatur gelar kesarjanaan yang disesuaikan dengan bidang keilmuan, akhirnya program studi tadris bahasa Inggris juga bergelar S.Pd (Sarjana Pendidikan). Dengan demikian mereka mendapat perlakuan dan hak yang sama dengan alumni perguruan tinggi umum.

Untuk mengantisipasi hambatanhambatan di atas, dan bahkan hanya sekedar untuk tetap survive dalam konotasi yang wajar, ada beberapa hal yang mendesak untuk dilakukan: (1) Pendidikan Islam hendaknya lebih adaptif, akomodatif, dan meninggalkan status quo; (2) Pendidikan Islam harus menuju integrasi antara ilmu agama dan ilmu umum; (3) Pendidikan Islam hendaknya memperhatikan muatan Bahasa Asing yang lebih intens, utamanya Bahasa Arab dan Bahasa Inggris; (4) Pendidikan Islam didesain dan di manage sedemikian rupa sehingga mampu menumbuhkan kemampuan untuk berswadaya dan mandiri dalam kehidupan; Lembaga-lembaga pendidikan Islam makin mempertegas komitmennya untuk memantapkan dirinya sebagai lembaga ynag berlabelkan Islam; dan (6) Para pakar pendidikan Islam perlu segera meretas problema internal keilmuan dalam pendidikan Islam.

Ketika hambatan-hambatan bisa dicarikan solusi terbaik, maka kemungkinan besar pendidikan Islam bisa survive secara nasional. Sehingga keberadaan pendidikan bisa memberikan kontribusi dalam pembangunan nasional dan diperhitungkan dalam skala nasional.

\section{KESIMPULAN}

Pendidikan Islam di Indonesia telah mengalami perjalanan yang panjang hingga akhirnya mendapat pengakuan secara nasional. Pengakuan tersebut tertuang dalam regulasi yang mendukung dan memperkuat eksistensi pendidikan Islam secara nasional. Dalam perjalanannya, pendidikan Islam tentunya mengalami berbagai macam hambatan dan kendala, baik secara internal maupun eksternal. Oleh karena itu, perlu upaya penguatan terhadap posisi pendidikan Islam dalam sistem pendidikan nasional. Penguatan tersebut ditunjukkan oleh lembaga dan SDM pendidikan Islam itu sendiri, baik secara kuantitas maupun kualitasnya. Pendidikan harus terdepan dalam segala hal, sehingga eksistensinya bisa diakui secara nasional.

${ }^{35}$ Azzahra, 78. 


\section{REFERENSI}

Admin. (2017). Madrasah Aliyah Keagamaan Terbuka Untuk Umum. Retrieved 2020, from http://www.pendis.kemenag.go.id /index.php?a=detilberita\&id=8531.

Asrohah, H. (1999). Sejarah Pendidikan Islam. Jakarta: Logos.

Azra, A. (1999). Pendidikan Islam: Tradisi Dan Modernisasi Menuju Milenium Baru. Jakarta: Logo Wacana Ilmu.

Azzahra, R. (tt). Pendidikan Islam Dalam Sistem Pendidikan Nasional. Kebumen: PGMI STAINU.

Baharun, R. A. (2018). "Pendidikan Islam Dalam Sistem Pendidikan Nasional: Telaah Epistemologi Terhadap Problematika Pendidikan Islam." Jurnal Ilmiah Didaktika Vol. 19 No. 1, 34-49.

Daulay, H. P. (2006). Pendidikan Islam Dalam Sistem Pendidikan Nasional di Indonesia. Jakarta: Kencana.

Fitriani, M. M. (2011). "Problematika Pendidikan Islam Sebagai Sub Sistem Pendidikan Nasional di Era Global." Jurnal at-Tahrir Vol. 11 No. 2, 303-325.

Hasbullah. (1996). Kapita Selekta Pendidikan. Jakarta: Rajawali Pers.

Hasbullah. (1996). Sejarah Pendidikan Islam di Indonesia: Lintasan Sejarah Pertumbuhan dan Perkembangan. Jakarta: LKiS.

Huda, A. K. (2001). Paradigma Pendidikan Islam. Semarang: Pustaka Pelajar.

Ismail. (2010). "Politik Pendidikan Madrasah di Indonesia Pasca Kemerdekaan: 1945-2003". Jurnal Ta'dib Vol. XV No. 02, 165-212.

Maksum. 1999. Madrasah: Sejarah dan Perkembangannya. Jakarta: Logos

Masykur, H. (2015). Eksistensi dan Fungsi Pendidikan Agama Islam dalam Sistem Pendidikan Nasional.
(Skripsi). Salatiga: Jurusan PAI, FTIK IAIN Salatiga.

Muhaimin. (2005). Pengembangan Kurikulum Pendidikan Agama Islam di Sekolah, Madrasah, dan Perguruan Tinggi. Jakarta: PT Raja Grafindo Persada

Nursikin, M. (2018). "Eksistensi Madrasah dan Sekolah Islam sebagai Lembaga Pendidikan Islam dalam Sistem Pendidikan Nasional: Studi Kasus di MAN Yogyakarta III dan SMA Muhammdiyah 1 Yogyakarta." Jurnal Istawa: Jurnal Pendidikan Islam Vol. 3 No. 1, 27-58.

Rahim, H. (2005). Madrasah dalam Politik Pendidikan di Indonesia. Jakarta: Logos.

Salim, M. H. (2012). Studi Ilmu Pendidikan Islam. Yogyakarta: ArRuzz Media.

Samrin. (2015). "Pendidikan Agama Islam dalam Sistem Pendidikan Nasional di Indonesia." Jurnal alTa'dib Vol. 8 No. 1, 101-116.

Sanaky, H. (2004). Paradigma Pendidikan Islam. Yogyakarta: Safiria Insania Press

Soebahar, A. H. (2013). Kebijakan Pendidikan Islam: dari Ordinasi Guru sampai UU Sisdiknas. Jakarta: Rajawali Pers

Supiana. (2008). Sistem Pendidikan Madrasah Unggulan di MAN Insan Cendikia, MAN 1 Bandung, dan MAN Darussalam Ciamis. Jakarta: Badan Litbang dan Diklat Departemen Agama RI.

Yahya, M. D. (2014). "Posisi Madrasah dalam Sistem Pendidikan Nasional di Era Otonomi Daerah. Jurnal Khazanah Vol. XII No. 1, 78-101.

Zuhdi, M. (2006). Political and Social Influences on Religious School: a Historical Perspective on Indonesian Islamic School Curricula. Canada: McGill University 